\title{
The Effectiveness of Physical Fitness Learning Based on Motion Cards in Elementary School
}

\author{
I Nyoman Kanca \\ Sport Education Department, Post Graduate Program \\ Ganesha University of Education \\ Singaraja, Indonesia
}

\author{
Made Agus Wijaya*, Ketut Iwan Swadesi \\ Sport Department, Post Graduate Program \\ Ganesha University of Education \\ Singaraja, Indonesia \\ *wijaya.madeagus@undiksha.ac.id
}

\begin{abstract}
Physical education learning in Indonesia focuses on developing physical fitness, in which students are able to carry out daily activities without experiencing significant fatigue. The purpose of this study was to determine the effectiveness of physical fitness learning based on motion cards. This true experimental study used randomized pretest-posttest control group design as the same subject design. The population were 41 elementary schools in Singaraja, Buleleng regency. The participants involved were 262 students from 4 elementary schools which selected by a purposive random sampling technique. A test including physical fitness: squat thrust/burpee test, sit and reach, vertical jump, and push-up. Meanwhile, nontest included a formative class evaluation (FCE) questionnaire were used as research instrument. Data analysis was carried out by t-test 0.05 significance level. The result showed that $t$-count reached 2.31 which is above 0.05 and the average FCE score of students reached 2.82 (very good) from maximum score of 3.00. It can be concluded that physical fitness learning based on motion cards are proven to be effective in improving physical fitness learning outcomes of elementary school in Singaraja city, students feel impressed, gain new experience of motion that have not done before, learning and moving in a friendly atmosphere. Motion cards series were recommended to teach physical fitness activity for PJOK elementary school teachers.
\end{abstract}

Keywords-physcial fitness, formative class evaluation (FCE), motion cards

\section{INTRODUCTION}

Physical education, sports and health (PJOK) is one of the subjects that must be given to the students at the primary and secondary education levels that make a positive contribution in realizing students in reaching $21^{\text {st }}$ century competency. Physical health is one of PJOK subject objectives that can be seen from the physical fitness level of students. Unfortunately, students' level of physical fitness is still low both on local and national level. Students at second and third grade of SMA Negeri 4 Singaraja, Buleleng Bali academic year 2008/2009 are classified as very low in physical fitness level [1]. Besides, $91 \%$ of junior high school students in Buleleng regency had low physical fitness level which also can be categorized as very low [2].
In 2006, Sport Development Index (SDI) measurement used physical fitness as one of the dimensions and was conducted in the scale of national stated that $81.3 \%$ of Indonesian people have low and very low categories of physical fitness, there is only $1.08 \%$ of people in Indonesia are in the very good category [3]. Furthermore, [4] concluded that the time used for professional development is still relatively low, which is between 24-42 minutes per day. Teachers with less teaching loads tend to use the time to fulfil basic requirements, while teachers with many teaching loads use the time for productive activities.

Observations and interviews were conducted with elementary PJOK subject teachers in Buleleng regency. Those teachers were Made Yasa, Made Yudana, Gede Surya, Cening Merta, Wayan Suara, Wayan Wirasa, Made Widana, Ni Luh Suarining and Nyoman Swarsini. The result of observations and interviews showed that there were 2 (two) main problems in the management of PJOK learning at elementary school in Buleleng regency, namely, 1) the implementation of innovative learning models and 2) the use of attractive learning media, therefore, students are enthusiastic to do movements during learning process of PJOK subject.

Through previous study, PJOK learning media has developed based on motion cards with physical fitness series. The motion cards with the physical fitness series contains students' choice of movement activity on physical fitness material, positive values of PJOK subject, movement assignments and motivations to the students. A set of motion cards consists of 36 (thirty-six) physical fitness motion cards, namely muscle endurance, cardiorespiratory endurance, muscle strength, speed, power, balance, flexibility and coordination. One set of motion cards contains 3 variants of motion cards based on the movement difficulty level. Moreover, from 36 physical fitness motion cards, there are 12 motion cards in easy levels (cards with green color), 12 motion cards in medium levels (cards with yellow color), and 12 motion cards in hard or difficult levels (cards with red color). The following shows the shape of appearance of the physical fitness series motion cards used in elementary school. 


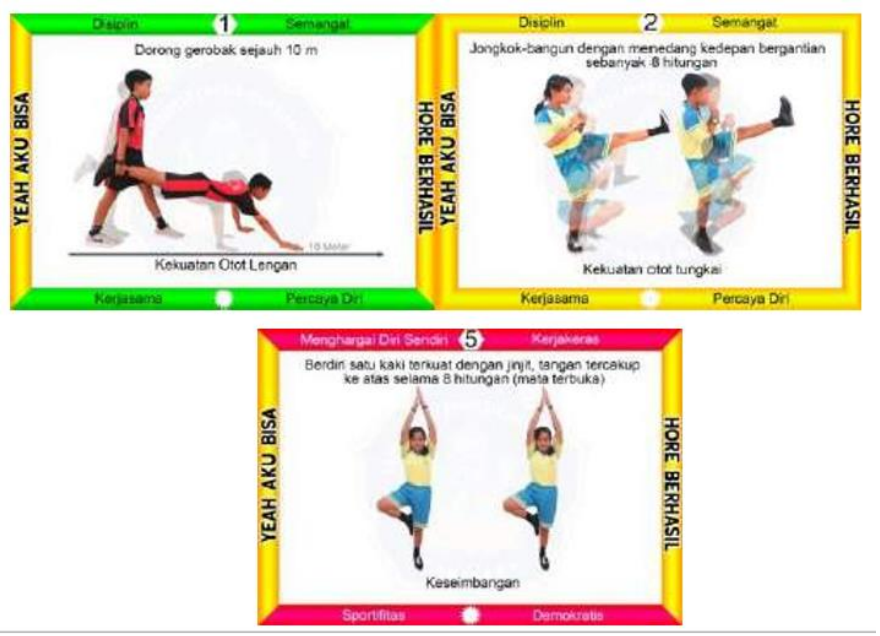

Fig. 1. Motion card series physical fitness in elementary school.I

Based on the explanation above, a study was conducted to examine deeply about the effectiveness of physical fitness based on physical fitness motion card in elementary school.

\section{MethodS}

This study is true experimental study by conducting true experimental design with a randomized pretest-posttest control group design with the same subject design [5].

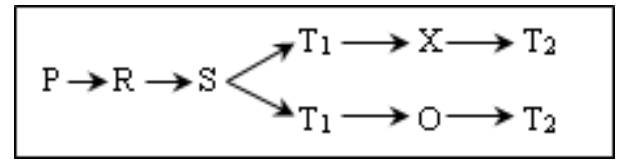

Explanation:

$\mathrm{P}=$ Population

$\mathrm{S}=$ Sample

T1 $=$ Pre-test

$\mathrm{T} 2=$ Post-test

$\mathrm{X}=$ Treatment group/cooperative learning model (MKOOP)

$\mathrm{O}=$ Control group/conventional learning model (MPK)

\section{A. Selecting Sample of the Study}

The population of this study was 41 elementary schools in Singaraja city, Buleleng regency. There were four criteria of selecting sample. 1) elementary school has at least 2 parallel learning groups, 2) academic qualifications of PJOK teachers at least undergraduate / S1 of physical, health, and recreation education, 3) teaching experience of PJOK teachers at least 5 years and 4) elementary school has outdoor spaces or field with at least badminton court. Purposive random sampling was conducted as the sampling technique. Further, there were 4 elementary schools that suitable with the criteria and used as sample of the study. Those elementary schools included SD Negeri 1 Banjar Jawa, SD Negeri 3 Banjar Jawa, SD Negeri 3 Kampung Baru and SD Negeri 4 Kampung Baru with a total of 262 students.

\section{B. Instrument of the Study}

The instrument of this study consisted of 1) a set of tests, namely a physical fitness test including squat thrust/burpee test, sit and reach, vertical jump and push-up, and 2) non-test, namely a Formative Class (FCE) Questionnaire. The data analysis technique used t-test at a significance level of $\alpha 0.05$. The following shows the validity and reliability of physical fitness instrument and FCE questionnaire norms. Results of validity and reliability of physical instruments according to [6] and formative class evaluation (FCE) questionnaire according to [7] can be seen as follows.

TABLE I. VALIDITY AND RELIABILITY OF PHYSICAL FITNESS INSTRUMENT

\begin{tabular}{|c|c|c|c|}
\hline \multirow[t]{2}{*}{ No } & \multirow[t]{2}{*}{ Test Items } & \multicolumn{2}{|c|}{ Degree of } \\
\hline & & Validity & Reliability \\
\hline 1. & Squat thrust (Burpee test) & 0.92 & 0.99 \\
\hline 2. & Sit and reach & 0.99 & 0.94 \\
\hline 3. & Vertical jump & 0.78 & 0.93 \\
\hline 4. & Sit-up & - & 0.99 \\
\hline
\end{tabular}

TABLE II. Formative Class Evaluation (FCE) Questionnaire

\begin{tabular}{|l|l|l|}
\hline \multicolumn{1}{|c|}{ Score } & \multicolumn{1}{|c|}{ FCE Score } & \multicolumn{1}{c|}{ Category } \\
\hline 5 & $2.77-3.00$ & Very good \\
\hline 4 & $2.58-2.76$ & Good \\
\hline 3 & $2.34-2.57$ & Moderate \\
\hline 2 & $2.15-2.33$ & Low \\
\hline 1 & $2.14-0$ & Very low \\
\hline
\end{tabular}

\section{RESULTS AND DISCUSSION}

\section{A. Results}

The study was conducted by referring to the learning hours of PJOK subject in elementary school. It was conducted in five meetings each including the pre-test and the post-test in each school with time allotment of $4 \times 30$ minutes/120 minutes. The following shows the descriptive data of each elementary school based on the implementation of learning model.

TABLE III. RESEARCH SAMPLE DESCRIPTIVE DATA

\begin{tabular}{|l|l|l|l|l|}
\hline \multirow{2}{*}{ School } & \multirow{2}{*}{ Learning Model } & \multicolumn{3}{|c|}{ Descriptive Data } \\
\cline { 3 - 5 } & & Mean & Median & \multicolumn{1}{|c|}{ SD } \\
\hline $\begin{array}{l}\text { 1. SD Negeri 1 Banjar } \\
\text { Jawa }\end{array}$ & MPKOOP & 0.69 & 1.00 & 2.26 \\
\cline { 2 - 5 } & MPK & 0.84 & 1.00 & 3.42 \\
\hline $\begin{array}{l}\text { 2. SD Negeri 3 Banjar } \\
\text { Jawa }\end{array}$ & MPKOOP & 1.48 & 1.00 & 1.92 \\
\cline { 2 - 5 } & MPK & 1.43 & 1.00 & 2.07 \\
\hline $\begin{array}{l}\text { 3. SD Negeri } \\
\text { Kampung Baru }\end{array}$ & MPKOOP & 2.00 & 2.00 & 1.53 \\
\cline { 2 - 5 } & MPK & 2.21 & 2.00 & 1.61 \\
\hline $\begin{array}{l}\text { 4. SD Negeri } \\
\text { Kampung Baru }\end{array}$ & MPKOOP & 1.26 & 1.00 & 1.95 \\
\cline { 2 - 5 } & MPK & 3.14 & 3.00 & 1.49 \\
\hline
\end{tabular}

Based on the data obtained, further, prerequisite test was conducted, namely the data normality test by using Kolmogorov-Smirnov test and the variance homogeneity test using Levene test. The following is the prerequisite test results. 
TABLE IV. Data Normality Test Results Using KilmogorovSMIRNOV

\begin{tabular}{|c|c|c|c|c|}
\hline \multirow[t]{2}{*}{ School } & \multirow[t]{2}{*}{$\begin{array}{c}\text { Learning } \\
\text { Model }\end{array}$} & \multicolumn{3}{|c|}{$\begin{array}{c}\text { Kolmogorov-Smirnov Test } \\
\text { Results }\end{array}$} \\
\hline & & Statistic & $d f$ & Sig. \\
\hline 1. SD Negeri 1 Banjar & MPKOOP & 0.128 & 39 & 0.105 \\
\hline Jawa & MPK & 0.113 & 37 & $0.200 *$ \\
\hline 2. SD Negeri 3 Banjar & MPKOOP & 0.124 & 29 & $0.200^{*}$ \\
\hline Jawa & MPK & 0.121 & 30 & $0.200 *$ \\
\hline 3. $\quad$ SD Negeri & MPKOOP & 0.139 & 36 & 0.077 \\
\hline Kampung Baru & MPK & 0.124 & 42 & 0.103 \\
\hline $\begin{array}{lll}\text { 4. } & \text { SD } & \text { Negeri }\end{array}$ & MPKOOP & 0.151 & 27 & 0.117 \\
\hline Kampung Baru & MPK & 0.173 & 22 & 0.086 \\
\hline
\end{tabular}

Based on Table IV, the significance value of the Kolmogorov-Smirnov normality test is in the range of 0.07 to 0.20 , greater than $\alpha(0.05)$, it can be stated that the data of this study obtained from a normally distributed population.

TABLE V. Homogeneity TeSt Results Data USING THE LEVENE TEST

\begin{tabular}{|l|l|l|l|l|}
\hline \multicolumn{1}{|c|}{ School } & \multicolumn{1}{|c|}{$\begin{array}{c}\text { Levene } \\
\text { Statistic }\end{array}$} & Df1 & Df2 & Sig. \\
\hline 1. SD Negeri 1 Banjar Jawa & 3.548 & 1 & 74 & 0.064 \\
\hline \begin{tabular}{l} 
2. SD Negeri 3 Banjar Jawa \\
\hline $\begin{array}{l}\text { 3. SD Negeri 3 Kampung } 0.334 \\
\text { Baru }\end{array}$
\end{tabular} & 1 & 57 & 0.98 \\
\hline $\begin{array}{l}\text { 4. SD Negeri 4 Kampung } \\
\text { Baru }\end{array}$ & 1.366 & 1 & 47 & 0.248 \\
\hline
\end{tabular}

The calculated significance value (p-value) of the Levene test results is in the range of 0.06 to 0.56 , greater than $\alpha(0.05)$, it can be stated that the variance of this study data is homogeneous. The prerequisite test results stated that the research data obtained from a population that is normally distributed and homogeneous. Therefore, it can be continued to test the hypothesis using the t-test at the 0.05 significance level. The following shows the results of the t-test of this study.

TABLE VI. RESUlt OF T-Test (ONE-SAMPle TeSt)

\begin{tabular}{|c|c|c|c|c|c|c|}
\hline \multirow{3}{*}{ School } & \multicolumn{6}{|c|}{ Test value $=0$} \\
\hline & \multirow[t]{2}{*}{$t$} & \multirow[t]{2}{*}{$d f$} & \multirow[t]{2}{*}{$\begin{array}{l}\text { Sig. }(2- \\
\text { tailed })\end{array}$} & \multirow[t]{2}{*}{$\begin{array}{c}\text { Mean } \\
\text { Differ } \\
\text { ence }\end{array}$} & \multicolumn{2}{|c|}{$\begin{array}{l}95 \% \text { Confidence } \\
\text { Interval of the } \\
\text { Difference }\end{array}$} \\
\hline & & & & & Lower & Upper \\
\hline $\begin{array}{l}\text { 1. SD Negeri } \\
\text { Banjar Jawa }\end{array}$ & \begin{tabular}{l|l}
12.318 \\
\end{tabular} & 75 & 0.023 & 0.763 & 0.11 & 1.42 \\
\hline $\begin{array}{l}\text { 2. SD Negeri } \\
\text { Banjar Jawa }\end{array}$ & 35.664 & 58 & 0.000 & 1.458 & 0.94 & 1.97 \\
\hline $\begin{array}{l}\text { 3. SD Negeri } \\
\text { Kampung Baru }\end{array}$ & \begin{tabular}{l|l}
3 & 11.895
\end{tabular} & 77 & 0.000 & 2.115 & 1.76 & 2.47 \\
\hline $\begin{array}{l}\text { 4. SD Negeri } \\
\text { Kampung Baru }\end{array}$ & 47.425 & 48 & 0.000 & 2.102 & 1.53 & 2.67 \\
\hline
\end{tabular}

From Table VI, it can be seen that obtained t-count result from 2.31 to 11.2 , and sig. or $p$-value $=0.000<\alpha=0.05$. it can be stated that there are significant differences in physical fitness learning outcomes between the treatment group and the control group. Therefore, cooperative learning model with physical fitness motion cards media has been proven to be effective to be used in improving students' physical fitness learning outcomes of elementary school in Singaraja city.

Furthermore, the effectiveness of learning according to students' opinions as stated in the formative class evaluation (FCE) questionnaire was also measured in this study. The results of the students' FCE scores in Buleleng regency is shown in the following table.

TABLE VII. The RESUlt OF STUDENTS' FCE SCORES IN ELEMENTARY SCHOOL

\begin{tabular}{|l|l|l|l|}
\hline No & \multicolumn{1}{|c|}{ School } & \multicolumn{1}{|c|}{$\begin{array}{c}\text { FCE } \\
\text { Score }\end{array}$} & \multicolumn{1}{|c|}{ Category } \\
\hline 1. & SD Negeri 1 Banjar Jawa & 2.80 & Very good \\
\hline 2. & SD Negeri 3 Banjar Jawa & 2.87 & Very good \\
\hline 3. & SD Negeri 3 Kampung Baru & 2.89 & Very good \\
\hline 4. & SD Negeri 4 Kampung Baru & 2.70 & Good \\
\hline Average & 2.82 & Very good \\
\hline
\end{tabular}

Based on the FCE results, it can be stated that the mean of FCE score is 2.82 from a maximum score 3.00 . besides, it can be categorized as very good criteria. Further, based on students' opinion of FCE questionnaire, physical fitness learning based on motion cards is very good to be implemented. It is supported by the conditions that students feel impressed, get experience by doing new movement that they never did before, do motion assignments seriously and happily, do not feel forced, learn and move in a friendly atmosphere.

\section{B. Discussion}

Physical fitness material is very important to be conducted for students in PJOK subject especially in elementary school. The National Association of Sport and Physical Education's (NASPE) has identified 20 (twenty) characteristics of physically educated students who were grouped into 5 (five) main aspects, including being physically fit and participating regularly in physical activities [8]. Physical fitness activities are related to the mechanics of body performing motion activities, components of physical fitness and body posture. From 20 characteristics, there are at least 4 characteristics related to physical fitness, namely (1) assessing, improving and maintaining physical fitness, (2) designing a physical fitness program in accordance with the principles of exercise but not harmful, (3) participating in the health coaching program through physical activity at least 3 times per week, and (4) choosing and regularly participating in physical activities in daily life.

In establishing the characteristics of students who are physically educated can be realized if the PJOK learning program is designed and implemented in a professional manner. Besides, it is also supported by adequate time allotment in the curriculum and the availability of sufficient equipment and facilities [9]. Furthermore, the implementation of education used to build better and literate generation will not 
be complete without physical, sports and health education (PJOK) subject [10]. Those statements above were used as references and to support this study in designing and developing series of motion activities card, in which every movement in the motion cards designed by the researcher has been being discussed with the PJOK teachers of elementary schools in a focus group discussion (FGD), further, the cards were validated by motion exercise experts. Therefore, the movements were in accordance with the students' growth and development, paying attention to the safety, giving comfort and safety situation to the students as well as varied motion assignments. In order to support the implementation of the motion cards development activity, a study is conducted not only to improve motion cards but also develop equipment and facility used in learning process by using this motion cards [11].

PJOK learning in elementary school is guided to movement vocabulary and movement grammar which later become students' identity [12]. Students' movement vocabulary is related to the way students recognize, learn and master various type of motion by giving attention to various things, including body awareness and environment awareness. Meanwhile, provisions of motion are related to the procedure or technique of doing those movements. The Centers for Disease Control (SDS) in the United States has listed physical education as one of eight components in developing school health programs [13].

The implementation of cooperative learning model by using physical fitness series motion cards as a media for students in elementary school was the main focus of this study. One of the important stages in the cooperative learning is group formation and processing. Participating in group processing facilitates students' understanding, personal and social development as they recognize how they deal with problem solve it, guide students to work together and cooperatively to overcome problem or difficulty that they might find during PJOK learning, help students to know the meaning of struggling, and develop new understandings among their group members. PJOK teacher during managing and facilitating students in the class always pay attention to the student activity during learning and create happy and comfortable atmosphere [14]. Moreover, feeling happiness and pleasure in learning PJOK can increase students' active participation in learning and build active learning.

Cooperative learning model assisted with the series of physical fitness motion cards in PJOK learning that is implemented in this study is student-centered learning oriented. Students of elementary school in Buleleng regency get learning experience and motion assignment in the productive situation including happy, interactive, communicative, inspiring, challenging and motivating for the students to participate actively. Through this cooperative learning, it can be expected that creativity and independence in accordance with the talents, interests, physical and psychological development of students get adequate time and place in the learning. The PJOK teachers during learning process act as a guide, motivator, facilitator, consultant and dynamic learning companion [15]. The statement above was in accordance with the innovative learning paradigm that are currently being implemented by the government.

PJOK teachers need to conduct affective learning as the main objectives of PJOK learning to help students learn to respect themselves and understand other conditions, respect diversity, give contribution to others, become independent learners in solving their own problem, do equal portion in terms of contribution and performance [16].

Previous relevant study related to the cooperative learning model can be described as follows. First study concluded that the basic-motion based cooperative learning model with motion cards is proven empirically and practically implemented by teachers and students, it is effective in improving basic movement skills of fourth grade students of elementary school in Buleleng district [17], second study found that the implementation of Fundamental Motor Skill (FMS) learning based on cooperative learning improved students' achievement in FMS learning [18]. Third study stated that the cooperative learning model in schools provided a learning experience through positive students' interactions, increased self-confidence and guided students group to create conducive learning environment in achieving learning goals [19]. Forth study stated that the cooperative learning model is one of the learning models that are effectively used in learning. Through this learning model, students learn and work in groups to achieve learning goals. Further, it explained that introducing a cooperative learning model in PJOK subject is the start or the right beginning in helping students of elementary school to acquire knowledge, skills and attitudes to be productive person while physically engaged in a society or social community activity [20]

\section{CONCLUSION}

Based on the result of the study and the discussion, it can be concluded that physical fitness learning based on a series of motion cards are proven to be effective in improving physical fitness learning outcomes of elementary school in Singaraja city. Besides, it can also create a condition that students feel impressed, gain new experience in doing motion activity that was never done before, learn and move in a friendly atmosphere. It can be stated that motion cards are recommended for PJOK elementary school teachers to be used in PJOK subject especially in teaching physical fitness activity.

\section{ACKNOWLEDGMENT}

The researcher thanks and appreciation goes to the rector of Ganesha University of Education who was willing to finance this study and we gratefully thank and feel proud of the hard work and commitment of the PJOK teachers in Buleleng regency who were actively participated during this research. 


\section{REFERENCES}

[1] I. Ketut, “'Korelasi Antara Vo2Maks Dengan Prestasi Belajar Siswa Kelas XI Dan XII SMA Negeri 4 Singaraja.' Laporan Penelitian.” UNDIKSHA, 2008.

[2] M. Budiawan and dkk, "Ujicoba Kartu Kendali Menuju Tubuh Bugar Dan Ideal (KKTBI) Pada SMP Negeri Di Kota Singaraja Provinsi Bali," 2011.

[3] T.C. Mutohir and A. Maksum, "Sport Development Index: Alternatif Baru Mengukur Kemajuan Pembangunan Bidang Keolahragaan (Konsep, Metodologi Dan Aplikasi)," Jakarta: Index, 2007.

[4] A. Maksum, "Kualitas Guru Pendidikan Jasmani Di Sekolah: Antara Harapan Dan Kenyataan," 2010.

[5] N. Dantes, "Metode Penelitian, Yogyakarta; CV," Andi Offset, 2012.

[6] B.L. Johnson and J.K. Nelson, "Practical Measurements for Evaluation in Physical Education.," 1969.

[7] M.A.K. Wijaya, "Uji Coba Instrumen Baku Evaluasi Pembelajaran Dikjasor Di SLTP Negeri Se-Kota Surabaya.” Surabaya: Deputi Bidang Pemberdayaan Olahraga, Kemenegpora Republik Indonesia, 2006.

[8] M.L. Krotee and C.A. Bucher, Management of Physical Education and Sport, Thirteenth. USA: USA: McGraw-Hill, 2007.

[9] A. Abdullah, "Pendidikan Jasmani Dan Olahraga Di Lembaga Pendidikan Menengah Dan Tinggi Dalam Perkembnagan Olahraga Terkini, Kajian Para Pakar.” Jakarta: PT Raja Grafindo Persada, 2003.

[10] Harsuki, Tantangan Pendidikan di Indonesia dalam Membangun Generasi Emas. Jakarta: PPs UNJ, 2014.

[11] Peraturan Pemerintah RI, Nomor 32 Tahun 2013 tentang Standar Nasional Pendidikan, Penjelasan Pasal 77I Ayat 1 Huruf H. 2013.
[12] B. Crum, "From Crisis to Revival-on Justification of PE as a School Subject and PE Curriculum Development in The Netherlands," Japanese J. Sport Educ. Stud., vol. 28, no. 2, pp. 43-49, 2009.

[13] K.T. Thomas, A.M. Lee, and J.R. Thomas, Physical education methods for elementary teachers. Human Kinetics, 2008.

[14] S. Sutherland, P.T. Stuhr, J. Ressler, C. Smith, and A. Wiggin, "A Model for Group Processing in Cooperative Learning," J. Phys. Educ. Recreat. Danc., vol. 90, no. 3, pp. 22-26, 2019.

[15] J.R. Lorusso, S.M. Pavlovich, and C. Lu, "Developing Student Enjoyment in Physical Education,” Phys. Heal. Educ. J., vol. 79, no. 2, p. 14, 2013.

[16] A. Casey and J. Fernandez-Rio, "Cooperative Learning and the Affective Domain," J. Phys. Educ. Recreat. Danc., vol. 90, no. 3, pp. 12-17, 2019.

[17] M.A. Wijaya, "Developing Fundamental Movement Based Cooperative Learning Model In Primary School," Indones. J. Educ. Rev., vol. 2, no. 1, pp. 13-24, 2015.

[18] T.B. Norito, F. Dlis, A.S. Hanif, and M. Iqbal, "Implementing Cooperative Learning in Physical Education and Sport to Improve Children Fundamental Movement Skill," J. Educ. Heal. Sport, vol. 9, no. 7, pp. 390-403, 2019.

[19] H. Bensikaddour, D. Mokrani, A. benklaouz Touati, H. Benzidane, and M. Sebbane, "The Importance Of The Practice Of Competitive Games Kid's Athletics In Physical Education For College Students (11-12 Years) Using The Cooperative Learning Strategy," Eur. Sci. J., vol. 11, no. 32, 2015.

[20] B.D. Bradford, C.N. Hickson, and A.K. Evaniew, "The Cooperative Learning Equation: An Effective Approach in Elementary School Physical Education,” Phys. Heal. Educ. J., vol. 80, no. 3, p. 6, 2014. 